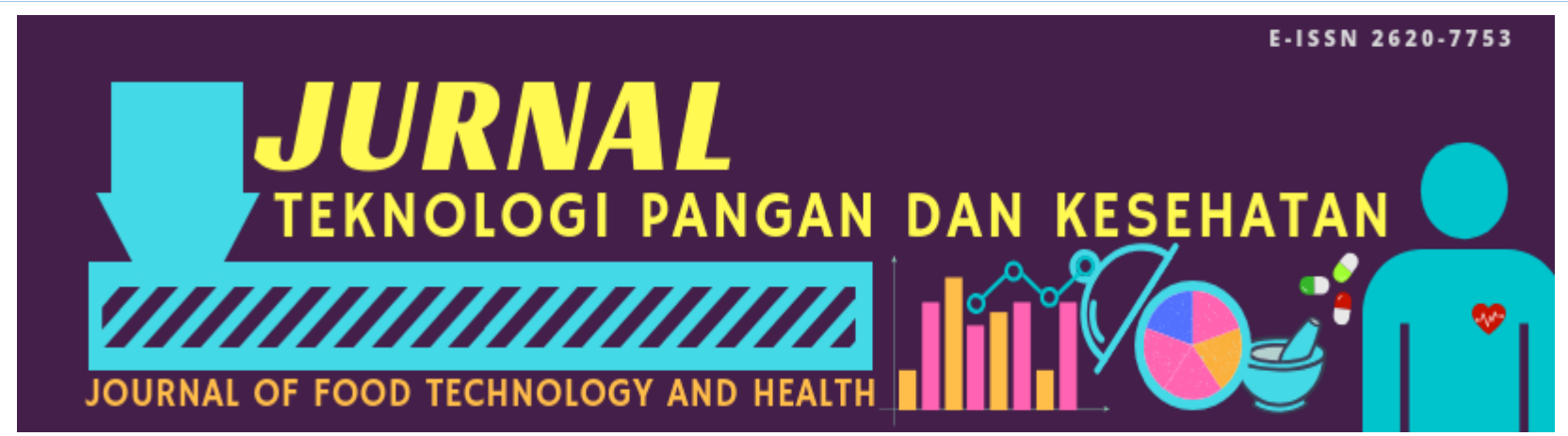

Volume 1 Nomor 2 Tahun 2019

Hasil Penelitian§

Diterima 13 Sept 2019

Disetujui 30 Des 2019

\title{
MUTU SAUERKRAUT KUBIS DAN WORTEL GRADE RENDAH DENGAN KONSENTRASI GARAM YANG BERBEDA
}

\author{
Ranny Nakdiyani ${ }^{1 *}$, Siti Chairiyah Batubara ${ }^{1}$ \\ ${ }_{1}^{1}$ Universitas Sahid Jakarta, Jl. Prof. Dr. Soepomo No.84, Menteng Dalam, Tebet, Jakarta Selatan 12870
}

\begin{abstract}
ABSTRAK: Garam adalah bahan yang mempengaruhi kualitas fermentasi sauerkraut. Garam digunakan untuk menghilangkan air dari sayuran dan digunakan oleh bakteri asam laktat untuk tumbuh. Kubis dan wortel kelas rendah dapat diolah dengan sauerkraut untuk meningkatkan nilai ekonomi. Inti dari penelitian ini adalah untuk mendapatkan konsentrasi garam yang dapat memanfaatkan kol dan wortel sauerkraut terbaik. Desain penelitian yang digunakan adalah Rancangan Acak Lengkap (RAL) dengan satu faktor yang terdiri dari 4 taraf (A1: 2,5\%; A2: 5\%; A3: 7,5\%; A4: 10\%) dan 4 pengulangan. Kualitas Sauerkraut dianalisis dengan uji organoleptik (mutu hedonik dan hedonik), uji fisik (susut bobot), uji kimia (pH, kadar air dan total padatan terlarut), vitamin $\mathrm{C}$ dan konsentrasi asam laktat. Data diolah secara statistik menggunakan aplikasi SPSS dengan analisis satu arah (ANOVA). Tindak lanjut Duncan dilakukan untuk mengetahui perbedaan antara perlakuan jika ANOVA memiliki efek yang signifikan. Formulasi terbaik adalah sauerkraut dengan konsentrasi garam 2,5\%. Selain itu sauerkraut memiliki penurunan berat badan $4,55 \%$, keasaman ( $\mathrm{pH}$ ) $3,70 \%$, kadar air $91,11 \%$, total padatan terlarut 7,40 Brix, vitamin C 3,29 mg / $100 \mathrm{~g}$ dan asam laktat 1,86\%.
\end{abstract}

Kata Kunci: Sauerkraut,Garam, Fermentasi

ABSTRACT: Salt is an ingredient that affects the quality of sauerkraut fermentation. Salt is used to remove water from vegetables that are used as lactic acid to grow. Low grade class of cabbage and carrot can be processed sauerkraut to increase economic value. The main of this research was to get concentration of salt that can be preserve the best sauerkraut cabbage and carrot. The research design used was Completely Randomized Design (CRD) with one factor consisting of 4 treatments levels $(A 1: 2,5 \% ; A 2: 5 \% ; A 3: 7,5 \% ; A 4: 10 \%)$ and 4 repetitions. Sauerkraut's quality analized by organoleptic test (hedonic and hedonic quality), physical test (weight loss test), chemical test ( $\mathrm{pH}$, water content and total dissolved solids), vitamin $C$ and lactic acid concentration. Data was processed statistically using SPSS application with one way analysis (one ways ANOVA). Duncan's follow-up was carried out to find out the differences between treatments if ANOVA had a significant effect. The best formulation is sauerkraut with 2,5\% salt concentration. In addition sauerkraut has weight loss $4,55 \%$, acidity (pH) $3.70 \%$, water content $91,11 \%$, total dissolved solid 7,40 Brix, vitamin C 3,29 mg/100 g and lactic acid 1,86\%.

Keywords: Sauerkraut, Salt, Fermentation

\footnotetext{
*Email korespondensi: rannynakd@gmail.com
} 


\section{PENDAHULUAN}

Komoditi sayur di pasaran digolongkan menjadi tingkat (grade) berdasarkan atribut mutu (warna, ukuran, bentuk). Demikian juga dengan wortel dan kubis. Kubis dan wortel dengan grade tinggi umumnya menjadi incaran utama konsumen terutama kalangan menengah ke atas dan umumnya dijual di supermarket atau hotel-hotel. Adapun wortel dan kubis grade rendah mempunyai nilai jual yang rendah dan hanya dipasarkan di pasar tradisional.

Kubis dan wortel grade rendah dapat diolah menjadi sauerkraut untuk memberikan nilai tambah. Sauerkraut adalah acar sayur kubis. Kubis dibersihkan, dikeluarkan bagian yang cacat, sakit dan kotor, dicuci kemudian iiris selebar kira-kira $5 \mathrm{~mm}$, dengan proses yang dimulai oleh bakteri Leuconostoc mesenteroides, lalu diteruskan oleh spesies yang lebih tahan terhadap keadaan yang lebih asam seperti Lactobacillus brevis, Lactobacillus plantarum dan Pediococcus cerevisae (Muchtadi et al., 2013). Sauerkraut merupakan produk fermentasi yang dibuat dengan cara dengan menambahkan garam konsentrasi tertentu pada irisan kubis (Ika dan Yenny, 2010). Sauerkraut juga dapat dikreasikan sesuai dengan cita rasa Indonesia yaitu dengan menggunakan cabai dan bawang putih (Hayati et al., 2017).

Menurut Koswara (2009), kol segar yang difermentasi menjadi sauerkraut menggunakan garam dengan konsentrasi tertentu, sehingga tidak perlu ditambahkan mikroorganisme lain sebagai starter (inoculum) atau ragi, karena bakteri asam laktat sudah ada pada kol. Oleh karena itu garam mempunyai peran yang penting terhadap mutu sauerkraut yang dihasilkan. Adanya penambahan garam dengan konsentrasi yang berbeda bertujuan untuk mengetahui adanya pengaruh konsentrasi garam yang digunakan.

\section{BAHAN DAN METODE Bahan}

Bahan utama yang digunakan dalam pembuatan sauerkraut adalah garam non yodium, kubis grade rendah dan wortel grade rendah. Bahan-bahan kimia yang digunakan untuk analisis sampel yaitu Aquades, standar vitamin $\mathrm{C}$, asam metaphospat, tri fluoro asetat, standar asam laktat, aquabidest, 0,5\% $\mathrm{NH}_{4} \mathrm{H}_{2} \mathrm{PO}_{4}$ pH 2,8.

\section{Alat}

Alat-alat yang digunakan dalam pembuatan sauerkraut yaitu pisau, talenan, baskom, timbangan, toples, pemberat kaca, pH meter, gelas kimia, oven, desikator, cawan, blender, refraktometer, labu ukur $25 \mathrm{ml}$, pipet $0,50,1 \mathrm{ml}$, labu ukur $10 \mathrm{ml}$, penyaring 0,45 $\mu \mathrm{m}$, vial HPLC, ultrasonik, sentrifugasi, Kolom C18, 4,6 x 250 mm, 5 $\mu \mathrm{m}$, minisart $0,45 \mathrm{ml}$. Untuk peralatan yang digunakan uji organoleptik adalah piring kecil, sendok kecil, tisu, formulir organoleptik, dan pulpen.

\section{Metode Penelitian}

Penelitian ini dilakukan dengan 3 tahapan, yaitu penelitian tahap 1 dilakukan untuk mengetahui formulasi sauerkraut yang masih dapat diterima oleh panelis, formulasi yang akan digunakan pada penelitian utama adalah kubis + garam (Ika dan Yenny, 2010). Penelitian tahap 2 ini dilakukan untuk menentukan konsentrasi garam. Pada beberapa penelitian sebelumnya terdapat beberapa konsentrasi garam yang menghasilkan mutu terbaik. Ika dan Yenny (2010) menyatakan mutu sauerkraut terbaik menggunakan konsentrasi garam 3\%, (Hayati et al., 2016) dan Sri dan Handini (2016) menyatakan 2,5\% dan menurut Swain et al (2014) sebesar 2,5$10 \%$. Berdasarkan hal tersebut maka rentang konsentrasi garam yang digunakan adalah 2,5 - 10\%.

Dan penelitan tahap 3 ini bertujuan untuk penentuan mutu terbaik dari 
sauerkraut kubis dan wortel.

\section{Proses pembuatan sauerkraut}

Kubis segar yang telah dibuang bagian bonggolnya dicuci kemudian ditiriskan. Kupas wortel sampai bersih, buang bagian atas wortel kemudian cuci bersih. Lakukan perajangan tipis setebal 2-5 mm, masukkan ke dalam baskom, lakukan perajangan juga pada wortel setebal 2-5 mm, masukkan ke dalam baskom. Kemudian lakukan penggaraman dengan cara memberikan garam 2,5\%, $5 \%, 7,5 \%$ dan $10 \%$ (b/b) ke dalam rajangan kubis dan wortel kemudian remas-remas sampai keluar air sejumlah $35 \% \mathrm{~b} / \mathrm{v}$ dari kubis dan wortel. Masukkan ke dalam wadah, beri pemberat, pastikan kubis dan wortel terendam seluruhnya di dalam air, fermentasi selama 7 hari pada suhu ruang.

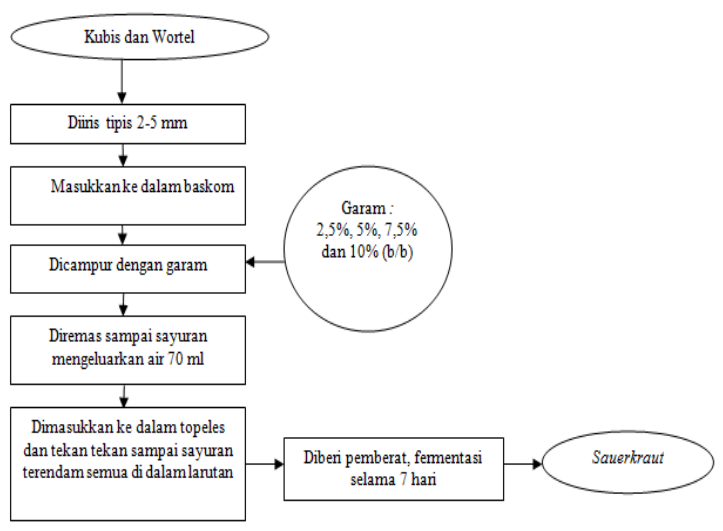

Gambar 1. Tahapan pembuatan sauerkraut (modifikasi Ika dan Yeni, 2010)

Selanjutnya sauerkraut dianalisis mutu fisik yaitu susut bobot, mutu kimia yaitu nilai $\mathrm{pH}$, kadar air, total padatan terlarut, mutu organoleptik meliputi uji hedonik (kesukaan) dan uji mutu hedonik terhadap warna, aroma, tekstur dan rasa dan mutu penunjang yaitu vitamin $\mathrm{C}$ dan asam laktat.

Tabel 1. Respon Ttingkat kesukaan pada skala hedonik

\begin{tabular}{lc}
\hline Spesifikasi & Nilai \\
\hline Amat sangat suka & 5 \\
Sangat suka & 4 \\
\hline
\end{tabular}

\begin{tabular}{ll}
\hline Suka & 3 \\
Agak Suka & 2 \\
Tidak Suka & 1 \\
\hline
\end{tabular}

Tabel 2. Skala uji mutu hedonik sauerkraut

\begin{tabular}{lll}
\hline Parameter & Mutu Hedonik & Skor \\
\hline Warna & Kuning pucat & 5 \\
& Kuning agak pucat & 4 \\
& Kuning agak gelap & 3 \\
& Kuning sedikit gelap & 2 \\
& Kuning gelap & 1 \\
\hline Aroma & Sangat kuat & 5 \\
& Agak kuat & 4 \\
& Agak tidak kuat & 3 \\
& Tidak kuat & 2 \\
& Sangat tidak kuat & 1 \\
\hline Tekstur & Sangat renyah & 5 \\
& Renyah & 4 \\
& Agak renyah & 3 \\
& Agak tidak renyah & 2 \\
& Tidak renyah & 1 \\
\hline Rasa & Sangat asam & 5 \\
& Asam & 4 \\
& Agak asam & 3 \\
& Agak tidak asam & 2 \\
& Tidak asam & 1 \\
\hline
\end{tabular}

Rancangan penelitian yang digunakan adalah Rancangan Acak Lengkap (RAL) satu faktor dengan empat taraf dan empat kali ulangan. Data yang diperoleh akan dianalisis menggunakan metode ANAVA menggunakan SPSS. Jika terdapat perbedaan nyata antar perlakuan, maka akan dilanjutkan dengan uji beda nyata dengan metode Duncan's Multiple Range Test (DMRT) pada taraf signifikansi $\alpha=$ 0.01 .

\section{HASIL DAN PEMBAHASAN}

Mutu sauerkraut dengan ditentukan melalui mutu fisik, kimia, organoleptik, penunjang.

\section{Mutu Fisik Susut Bobot}

Hasil uji ANOVA susut bobot sauerkraut menunjukkan bahwa tingkat signifikasi pada perlakuan berbagai 
konsentrasi garam yang berbeda yang ditambahkan untuk membuat sauerkraut $<0,01$ yang berarti $\mathrm{H}_{1}$ diterima, artinya terdapat pengaruh yang sangat nyata terhadap susut bobot pada sauerkraut. Berdasarkan uji ANOVA dengan hasil ada pengaruh sangat nyata maka dilanjutkan uji Duncan untuk mengetahui pada konsentrasi berapa yang memberikan perbedaan susut bobot.

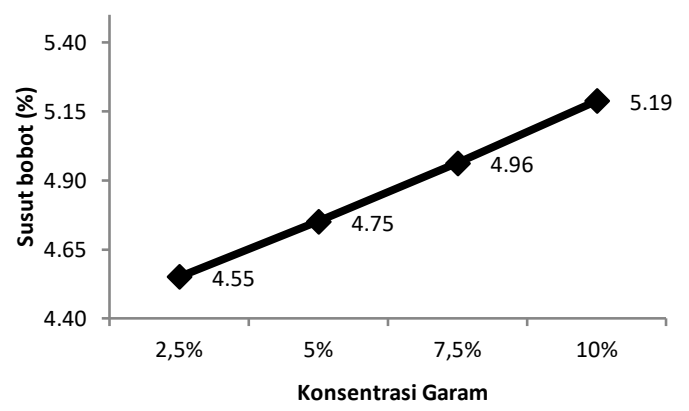

Gambar 2. Grafik rata-rata susut bobot (\%)

Hasil uji Duncan nilai rata-rata susut bobot pada sauerkraut berbeda sangat nyata pada taraf $\alpha=0,01$ untuk setiap perlakuan. Berdasarkan hasil pengamatan seiring bertambahnya formulasi konsentrasi garam pada sauerkraut terjadi kenaikan persentase susut bobot. Hal ini diduga terjadi karena sifat garam yang menarik air dari sayuran (Buckle et al, 2007) pada sauerkraut sehingga semakin tinggi konsentrasi garam maka terjadi kenaikan penyusutan bobot pada sayuran sauerkraut.

\section{pH}

Derajat keasaman (pH) merupakan salah satu parameter uji mutu kimia pada sauerkraut karena pH menentukan baik tidaknya sauerkraut yang dihasilkan. Hasil rata-rata $\mathrm{pH}$ sauerkraut secara berurut sebesar $3,70 \quad(2,5 \%) ; 3,80 \quad(5 \%) ; 4,45$ $(7,5 \%)$ dan 4,80 (10\%). Nilai rata-rata tertinggi yaitu pada konsentrasi garam $10 \%$ sebesar $4,80 \%$ dan nilai rata-rata terendah yaitu pada konsentrasi garam $2,5 \%$ sebesar 3,70 .
Hasil uji ANOVA pH sauerkraut menunjukkan bahwa tingkat signifikasi pada perlakuan berbagai konsentrasi garam yang berbeda yang ditambahkan untuk membuat sauerkraut $<0,01$ yang berarti $\mathrm{H}_{1}$ diterima, artinya terdapat pengaruh yang sangat nyata terhadap $\mathrm{pH}$ pada sauerkraut.

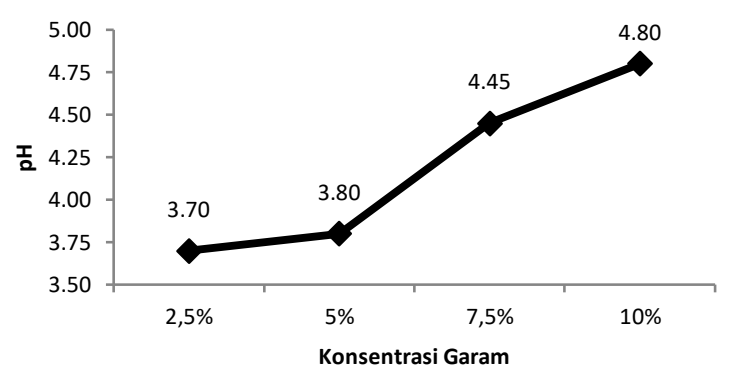

Gambar 3. Grafik rata-rata pH

Hasil uji Duncan nilai rata-rata $\mathrm{pH}$ pada sauerkraut berbeda sangat nyata pada taraf $\alpha=0,01$ untuk setiap perlakuan. Menurut Buckle et al (2007), bakteri asam laktat termasuk bakteri yang menghasilkan sejumlah besar asam laktat sebagai hasil akhir metabolisme gula (karbohidrat). Asam laktat yang dihasilkan dengan cara tersebut akan menurunkan nilai $\mathrm{pH}$ dari lingkungan pertumbuhannya dan menimbulkan rasa asam.

Bakteri paling cepat tumbuh dalam kondisi asam. Berdasarkan penelitian sebelumnya (Pundir dan Jain, 2010) menyatakan bahwa sauerkraut yang baik adalah yang mengandung $\mathrm{pH}$ berkisar antara 3,1-3,7. Demikian juga dengan hasil penelitian ini $\mathrm{pH}$ terbaik pada konsentrasi garam $2.5 \%$.

\section{Kadar Air}

Kadar air merupakan banyaknya air yang terkandung dalam bahan yang dinyatakan dalam persen. Rata-rata kadar air semakin rendah seiring dengan penambahan konsentrasi garam. 


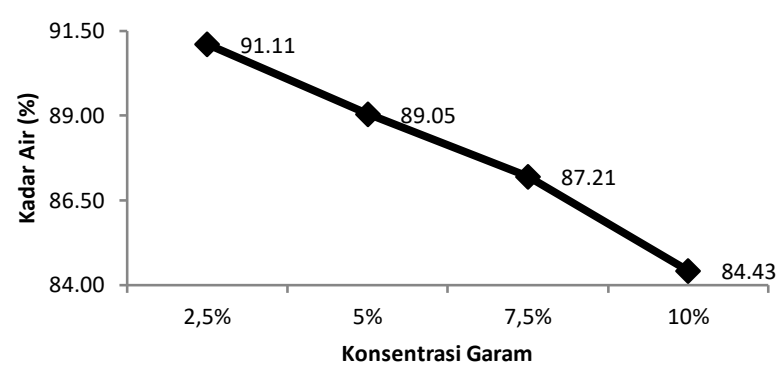

Gambar 4. Grafik rata-rata kadar air (\%)

Hasil uji ANOVA kadar air sauerkraut menunjukkan bahwa tingkat signifikasi pada perlakuan berbagai konsentrasi garam yang berbeda yang ditambahkan untuk membuat sauerkraut < 0,01 yang berarti H1 diterima, artinya terdapat pengaruh yang sangat nyata terhadap kadar air pada sauerkraut.

Hasil uji Duncan nilai rata-rata kadar air pada sauerkraut berbeda sangat nyata pada taraf $\alpha=0,01$ untuk setiap perlakuan. Menurut (Hayati et al., 2017), kadar air sayur kol segar varietas kol putih kepala bulat adalah 91,994\% sedangkan menurut Setyawan et al., (2013) kadar air wortel dalam keadaan segar yaitu 91,16\%. Berdasarkan hasil pengujian sauerkraut kubis dan wortel dapat dilihat semakin tinggi konsentrasi garam maka kadar air semakin rendah, hasil tersebut sesuai menurut penelitian sebelumnya (Hayati et al., 2017) yang menyatakan semakin tinggi konsentrasi garam semakin rendah kadar airnya. Menurut Muchtadi et al., (2013), garam berfungsi untuk mengeluarkan zatzat gizi dari jaringan bahan. Berdasarkan hasil pengamatan kadar air persen kadar air terbesar pada konsentrasi garam 2,5\%. Hal ini diduga karena semakin rendah konsentrasi garam semakin tinggi kadar airnya karena tidak banyak nutrisi dan air yang ditarik oleh garam yang sedikit jumlahnya.

\section{Total Padatan Terlarut}

Berdasarkan hasil pengujian sauerkraut kubis dan wortel dapat dilihat semakin tinggi konsentrasi garam maka semakin besar total padatan terlarut yang dinyatakan besarannya dalam satuan ${ }^{\circ}$ Brix. Menurut Subagjo (2007), Brix adalah jumlah zat padat semua yang larut (dalam gr) setiap 100 gr larutan.

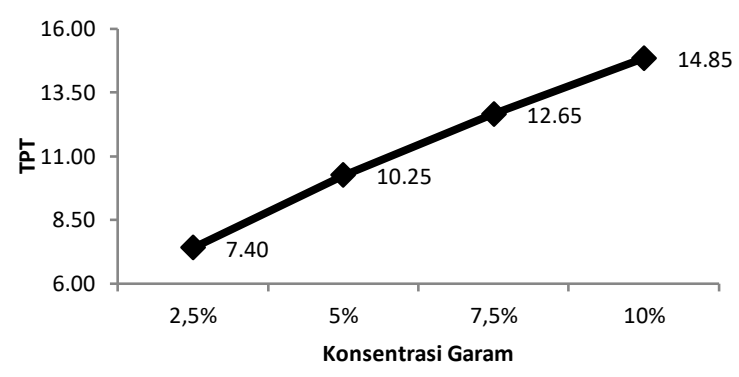

Gambar 5. Grafik rata-rata TPT (\%)

Hasil uji ANOVA total padatan terlarut sauerkraut menunjukkan bahwa tingkat signifikasi pada perlakuan berbagai konsentrasi garam yang berbeda yang ditambahkan untuk membuat sauerkraut < 0,01 yang berarti $\mathrm{H}_{1}$ diterima, artinya terdapat pengaruh yang sangat nyata terhadap total padatan terlarut pada sauerkraut.

Hasil uji Duncan nilai rata-rata total padatan pada sauerkraut sangat berbeda nyata pada taraf $\alpha=0,01$ untuk setiap perlakuan. Semakin tinggi nilai Brix menunjukkan semakin tinggi kandungan gulanya. Semakin besar jumlah garam yang ditambahkan maka semakin besar peristiwa difusi yang terjadi, garam $(\mathrm{NaCl})$ pada larutan osmosis akan membantu proses difusi lebih cepat masuk ke dalam jaringan buah.

\section{Mutu Organoleptik}

\section{Mutu Hedonik Warna}

Hasil uji ANOVA mutu hedonik warna sauerkraut menunjukkan bahwa tingkat signifikasi pada perlakuan berbagai konsentrasi garam yang berbeda yang ditambahkan untuk membuat sauerkraut < 0,01 yang berarti H1 diterima, artinya 
terdapat pengaruh yang sangat nyata terhadap mutu hedonik warna pada sauerkraut.

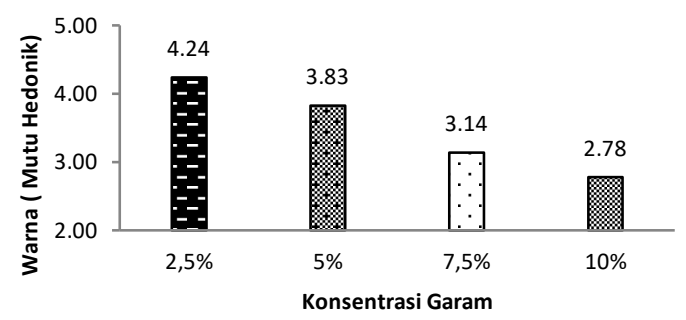

Gambar 6. Grafik Mutu Hedonik Warna

Hasil uji Duncan nilai rata-rata mutu hedonik warna pada sauerkraut berbeda sangat nyata pada taraf $\alpha=0,01$ untuk setiap perlakuan. Apabila jumlah garam yang terlalu banyak justru akan menunda fermentasi alamia, menyebabkan warna menjadi gelap, dan memungkinkan pula pertumbuhan khamir.

\section{Mutu Hedonik Aroma}

Hasil rata-rata mutu hedonik aroma terhadap sauerkraut dengan konsentrasi garam berbeda secara berurut sebesar $4,20(2,5 \%) ; 3,84$ (5\%); 3,20 (7,5\%); dan $2,86(10 \%)$. Nilai rata-rata tertinggi yaitu pada konsentrasi garam 2,5\% sebesar 4,20 dan nilai rata-rata terendah yaitu pada konsentrasi garam $10 \%$ sebesar 2,86. Ratarata mutu hedonik aroma mengalami penurunan tingkat kekuatan aroma seiring dengan penambahan konsentrasi garam.

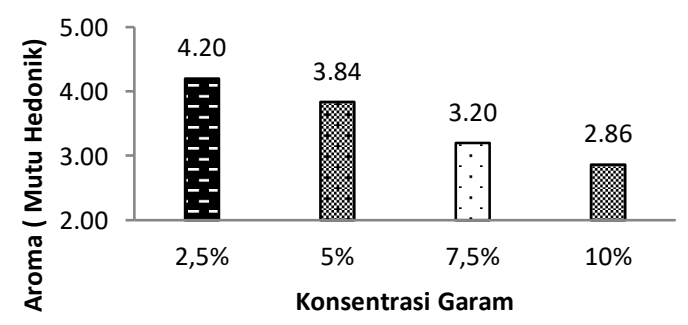

Gambar 7. Mutu Hedonik Aroma

Hasil uji ANOVA mutu hedonik aroma sauerkraut menunjukkan bahwa tingkat signifikasi pada perlakuan berbagai konsentrasi garam yang berbeda yang ditambahkan untuk membuat sauerkraut < 0,01 yang berarti $\mathrm{H} 1$ diterima, artinya terdapat pengaruh yang sangat nyata terhadap mutu hedonik aroma pada sauerkraut.

Hasil uji Duncan nilai rata-rata mutu hedonik aroma pada sauerkraut berbeda sangat nyata pada taraf $\alpha=0,01$ untuk setiap perlakuan. Semakin banyak penambahan garam menyebabkan aroma semakin tidak kuat karena kadar keasaman semakin berkurang.

\section{Mutu Hedonik Tekstur}

Hasil rata-rata mutu hedonik tekstur terhadap sauerkraut dengan konsentrasi garam berbeda secara berurut sebesar 4,18 (2,5\%); 4,10 (5\%); 3,53 (7,5\%); dan $3,13(10 \%)$. Nilai rata-rata tertinggi yaitu pada konsentrasi garam 2,5\% sebesar 4,18 dan nilai rata-rata terendah yaitu pada konsentrasi garam $10 \%$ sebesar 3,13. Ratarata mutu hedonik tekstur mengalami penurunan tingkat kerenyahan seiring dengan penambahan konsentrasi garam.

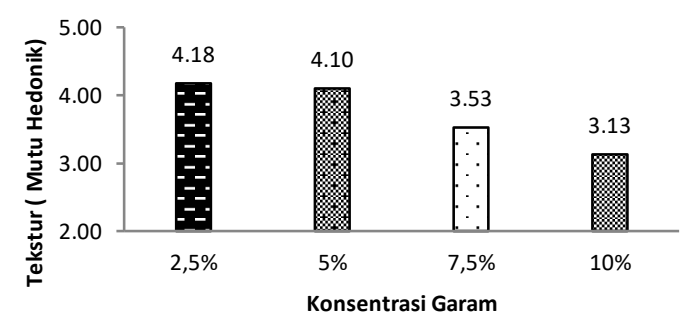

\section{Gambar 8. Grafik Mutu Hedonik Tekstur}

Hasil uji ANOVA mutu hedonik tekstur sauerkraut menunjukkan bahwa tingkat signifikasi pada perlakuan berbagai konsentrasi garam yang berbeda yang ditambahkan untuk membuat sauerkraut < 0,01 yang berarti H1 diterima, artinya terdapat pengaruh yang sangat nyata terhadap mutu hedonik tekstur pada sauerkraut.

Berdasarkan hasil uji Duncan dapat 
diketahui bahwa penambahan garam 2,5\% sangat tidak berbeda nyata $(\alpha=0,01)$ dengan penambahan garam $5 \%$, namun memberikan pengaruh sangat berbeda nyata $(\alpha=0,01)$ dengan penambahan garam $7,5 \%$ dan $10 \%$. Penambahan garam $5 \%$ sangat berbeda nyata $(\alpha=0,01)$ dengan penambahan garam $7,5 \%$ dan $10 \%$. Sedangkan penambahan garam 7,5\% sangat tidak berbeda nyata $(\alpha=0,01)$ dengan penambahan garam $10 \%$. Semakin banyak penambahan garam menyebabkan tekstur semakin tidak renyah karena semakin tinggi persentase garam maka air yang dikeluarkan oleh sayuran akan semakin banyak dan menimbulkan tekstur sayuran semakin lembek.

\section{Mutu Hedonik Rasa}

Hasil rata-rata mutu hedonik rasa terhadap sauerkraut dengan konsentrasi garam berbeda secara berurut sebesar 4,25 (2,5\%); 4,00 (5\%); 2,96 (7,5\%); dan $2,80(10 \%)$. Nilai rata-rata tertinggi yaitu pada konsentrasi garam 2,5\% sebesar 4,25 dan nilai rata-rata terendah yaitu pada konsentrasi garam $10 \%$ sebesar 2,80 . Ratarata mutu hedonik rasa mengalami penurunan tingkat keasaman seiring dengan penambahan konsentrasi garam.

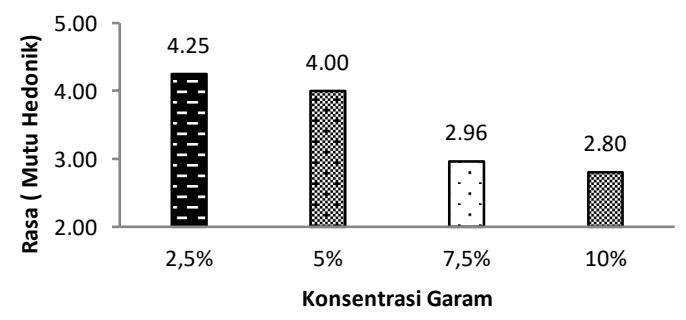

Gambar 9. Grafik Mutu Hedonik Rasa

Hasil uji ANOVA mutu hedonik rasa sauerkraut menunjukkan bahwa tingkat signifikasi pada perlakuan berbagai konsentrasi garam yang berbeda yang ditambahkan untuk membuat sauerkraut < 0,01 yang berarti $\mathrm{H}_{1}$ diterima, artinya terdapat pengaruh yang sangat nyata terhadap mutu hedonik rasa pada sauerkraut.

Berdasarkan hasil uji Duncan yang disajikan, dapat diketahui bahwa penambahan garam 2,5\% sangat tidak berbeda nyata $(\alpha=0,01)$ dengan penambahan garam $5 \%$ namun sangat berbeda nyata $(\alpha=0,01)$ dengan penambahan garam 7,5\% dan 10\%. Penambahan garam 5\% sangat berbeda nyata $(\alpha=0,01)$ dengan penambahan garam $7,5 \%$ dan $10 \%$. Sedangkan penambahan garam $7,5 \%$ sangat tidak berbeda nyata $(\alpha=0,01)$ dengan penambahan garam $10 \%(\alpha=0,01)$. Semakin banyak penambahan garam menyebabkan rasa asam semakin menurun karena kadar keasaman semakin berkurang.

\section{Hedonik Warna}

Hasil rata-rata hedonik warna terhadap sauerkraut dengan konsentrasi garam berbeda didapatkan rata - rata skala hedonik terhadap warna berkisar antara 3,26 - 4,52 (suka - sangat suka). Dengan nilai rata - rata tertinggi 4,52 (sangat suka) pada taraf perlakuan penambahan konsentrasi garam 5\% dan terendah 3,26 (suka) pada taraf perlakuan penambahan konsentrasi garam 10\%. Rata-rata mutu hedonik warna mengalami penurunan tingkat kesukaan terhadap warna sauerkraut seiring dengan penambahan konsentrasi garam.

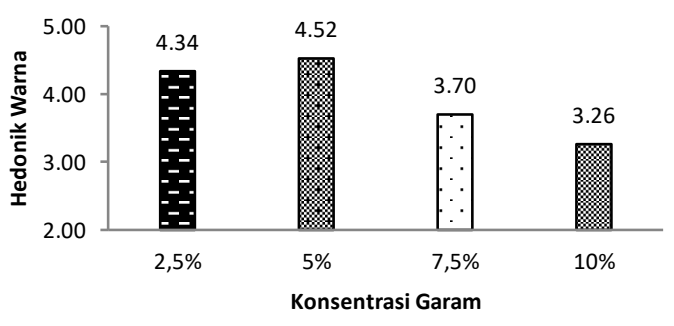

\section{Gambar 10. Grafik Hedonik Warna}

Hasil uji ANOVA hedonik warna sauerkraut menunjukkan bahwa tingkat signifikasi pada perlakuan berbagai 
konsentrasi garam yang berbeda yang ditambahkan untuk membuat sauerkraut < 0,01 yang berarti $\mathrm{H}_{1}$ diterima, artinya terdapat pengaruh yang sangat nyata terhadap hedonik warna pada sauerkraut.

Berdasarkan hasil uji Duncan diketahui bahwa konsentrasi garam 2,5\% sangat tidak berbeda nyata $(\alpha=0,01)$ dengan konsentrasi garam 5\%, namun dengan konsentrasi garam 7,5\% dan 10\% memberikan perbedaan yang sangat nyata $(\alpha=0,01)$. Penambahan garam 7,5\% memberikan perbedaan yang sangat nyata $(\alpha=0,01)$ dengan penambahan garam $10 \%$.

Menurut Huzaibah, Minarny dan Asrawaty (2018), yang menyatakan bahwa warna memengaruhi penerimaan suatu bahan pangan, karena umumnya penerimaan bahan yang pertama kali dilihat adalah warna. Warna yang menarik akan meningkatkan penerimaan produk. Sauerkraut dengan konsentrasi garam 5\% memberikan warna yang cerah dan segar dibandingkan dengan konsentrasi lainnya. Tingkat kesukaan yang paling tinggi mewakili warna yang paling disukai oleh para panelis adalah sampel dengan penambahan garam $5 \%$ dengan rataan sebesar 4,52 sangat suka.

\section{Hedonik Aroma}

Hasil rata-rata mutu hedonik aroma terhadap sauerkraut dengan konsentrasi garam berbeda didapatkan rata - rata skala hedonik terhadap aroma berkisar antara 2,78 - 3,19 (agak suka - suka). Dengan nilai rata - rata tertinggi 3,19 (suka) pada taraf perlakuan penambahan konsentrasi garam 7,5\% dan terendah 2,78 (agak suka) pada taraf perlakuan penambahan konsentrasi garam $10 \%$.

Hasil uji ANOVA hedonik aroma sauerkraut menunjukkan bahwa tingkat signifikasi pada perlakuan berbagai konsentrasi garam yang berbeda yang ditambahkan untuk membuat sauerkraut > 0,01 yang berarti H1 ditolak, artinya tidak terdapat pengaruh yang sangat nyata terhadap hedonik aroma. Pada tingkat signifikasi $(\alpha=0,05)$ menunjukkan bahwa konsentrasi garam yang berbeda memiliki pengaruh yang berbeda nyata terhadap aroma sauerkraut $(\operatorname{sig}<\alpha=0,05)$.

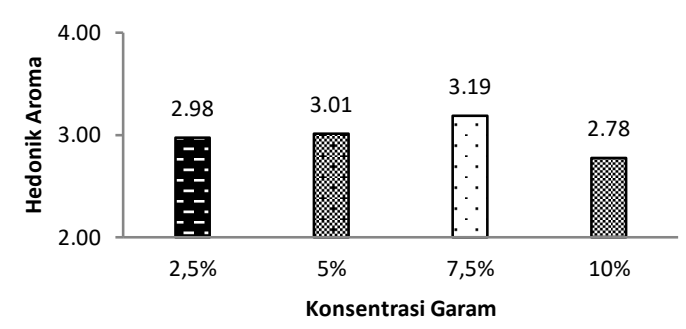

\section{Gambar 11. Grafik Hedonik Aroma}

Berdasarkan hasil uji Duncan dapat diketahui bahwa bahwa konsentrasi garam $2,5 \%$ dan $5 \%$ sangat tidak berbeda nyata $(\alpha=0,01)$ terhadap konsentrasi garam 7,5\% dan 10\%. Konsentrasi garam 7,5\% sangat berbeda nyata $(\alpha=0,01)$ dengan konsentrasi garam $10 \%$.

Tingkat kesukaan panelis yang paling tinggi mewakili aroma yang paling disukai oleh para panelis adalah sampel dengan penambahan garam 7,5\% dengan rataan sebesar 3,19 suka. Aroma khas fermentasi menyebabkan tingkat kesukaan terhadap sauerkraut rendah.

\section{Hedonik Tekstur}

Hasil rata-rata mutu hedonik tekstur terhadap sauerkraut dengan konsentrasi garam berbeda didapatkan rata - rata skala hedonik terhadap tekstur berkisar antara 3,19 - 4,40 (suka - sangat suka). Dengan nilai rata - rata tertinggi 4,40 (sangat suka) pada taraf perlakuan penambahan konsentrasi garam 2,5\% dan terendah 3,19 pada taraf perlakuan penambahan konsentrasi garam 10\%. Rata-rata mutu hedonik tekstur mengalami penurunan tingkat kesukaan terhadap tekstur sauerkraut seiring dengan penambahan 
konsentrasi garam.

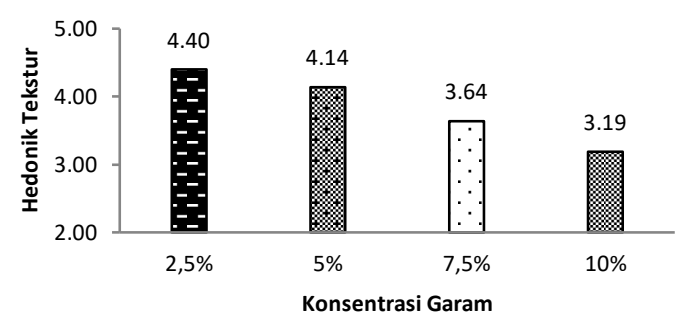

\section{Gambar 12. Grafik Hedonik Tekstur}

Hasil uji ANOVA hedonik tekstur sauerkraut menunjukkan bahwa tingkat signifikasi pada perlakuan berbagai konsentrasi garam yang berbeda yang ditambahkan untuk membuat sauerkraut < 0,01 yang berarti $\mathrm{H} 1$ diterima, artinya terdapat pengaruh yang sangat nyata terhadap hedonik tekstur pada sauerkraut.

Berdasarkan hasil uji Duncan dapat diketahui bahwa penambahan garam 2,5\% sangat tidak berbeda nyata $(\alpha=0,01)$ dengan konsentrasi $5 \%$ namun menunjukkan perbedaan sangat nyata $(\alpha=0,01)$ terhadap konsentrasi $7,5 \%$ dan $10 \%$. Konsentrasi 5\% sangat tidak berbeda nyata $(\alpha=0,01)$ dengan konsentrasi $7,5 \%$ namun menunjukkan sangat berbeda nyata terhadap konsentrasi $10 \%$. Konsentrasi $7,5 \%$ sangat tidak berbeda nyata $(\alpha=0,01)$ dengan konsentrasi 10\%. Tingkat kesukaan sauerkraut cenderung menurun. Hal ini disebababkan karena tekstur yang semakin tidak renyah dan lembek.

\section{Hedonik Rasa}

Hasil rata-rata mutu hedonik rasa terhadap sauerkraut dengan konsentrasi garam berbeda didapatkan rata - rata skala hedonik terhadap rasa berkisar antara 3,03 - 4,29 (suka - sangat suka). Dengan nilai rata - rata tertinggi 4,29 (sangat suka) pada taraf perlakuan penambahan konsentrasi garam 5\% dan terendah 3,03 (suka) pada taraf perlakuan penambahan konsentrasi garam 10\%.
Hasil uji ANOVA hedonik rasa sauerkraut menunjukkan bahwa tingkat signifikasi pada perlakuan berbagai konsentrasi garam yang berbeda yang ditambahkan untuk membuat sauerkraut < 0,01 yang berarti $\mathrm{H} 1$ diterima, artinya terdapat pengaruh yang sangat nyata terhadap hedonik rasa pada sauerkraut.

Berdasarkan hasil uji Duncan diketahui bahwa konsentrasi garam 2,5\% sangat tidak berbeda nyata a $(\alpha=0,01)$ dengan konsentrasi garam $5 \%$ namun sangat berbeda nyata $(\alpha=0,01)$ dengan konsentrasi garam $7,5 \%$ dan $10 \%$. Sedangkan konsentrasi garam $7,5 \%$ sangat tidak berbeda nyata $(\alpha=0,01)$ dengan konsentrasi garam $10 \%$.

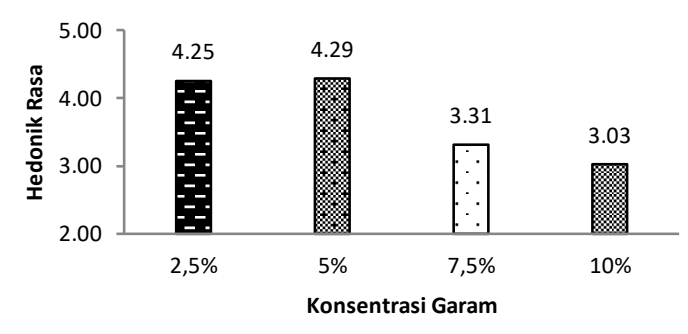

\section{Gambar 13. Grafik Hedonik Rasa}

Penurunan kesukaan terhadap rasa karena semakin tinggi konsentrasi garam semakin berkurang rasa asamnya namun cenderung ke pahit karena banyaknya garam yang ditambahkan, namun pada konsentrasi $2,5 \%$ rasa terlalu asam sehingga panelis lebih memilih konsentrasi 5\% karena memiliki rasa asam dan asin yang cukup.

\section{Uji Penunjang}

Data penunjang dipilih dari hasil sauerkraut terbaik yaitu dengan konsentrasi garam 2,5\%. Sauerkraut dengan konsentrasi $2,5 \%$ dipilih yang terbaik karena berdasarkan uji kimia yaitu pH pada konsentrasi tersebut pH terbaik terbentuk untuk pertumbuhan bakteri 
asam laktat yaitu pH 3,70. Sauerkraut ini mempunyai karakteristik: mutu hedonik terhadap warna kuning agak pucat, aroma agak kuat, tekstur renyah dan rasa asam.

\section{Vitamin C}

Nilai rata-rata vitamin C sauerkraut dengan konsentrasi garam 2,5\% adalah $3,29 \mathrm{mg} / 100 \mathrm{~g}$. Vitamin C tidak stabil dalam larutan alkali, tetapi cukup stabil dalam larutan asam. Vitamin C umumnya hanya terdapat di dalam pangan nabati, yaitu sayuran dan buah terutama yang asam, seperti jeruk, nenas, rambutan, pepaya, gandaria, dan tomat, vitamin C juga banyak terdapat di dalam sayuran daundaunan dan jenis kol.

\section{Asam Laktat}

Nilai rata-rata asam laktat dengan konsentrasi garam 2,5\% adalah 1.863\% (b/b). Nilai asam laktat yang terkandung dalam sauerkraut kubis dan wortel masuk dalam persyaratan SNI 01-2600-1992 mengenai syarat mutu sauerkraut yaitu masuk dalam rentang $1-2 \%(b / b)$.

\section{KESIMPULAN}

1. Hasil uji mutu fisik sauerkraut kubis dan wortel dengan konsentrasi garam yang berbeda memengaruhi sangat nyata susut bobot $(\alpha<0,01)$. Nilai susut bobot berkisar 4,55-5,19\%.

2. Hasil uji mutu kimia sauerkraut kubis dan wortel dengan konsentrasi garam yang berbeda memengaruhi sangat nyata $\mathrm{pH}$, kadar air, total padatan terlarut $(\alpha<0,01)$.

3. Hasil uji mutu hedonik sauerkraut kubis dan wortel memengaruhi sangat nyata parameter warna, aroma, rasa dan tekstur dengan $\alpha=0,01$ pada sauerkraut. Hasil uji hedonik menunjukkan konsentrasi garam yang berbeda menunjukkan pengaruh sangat nyata terhadap warna, rasa dan tekstur dengan $\alpha=0,01$ pada sauerkraut. Pada parameter hedonik aroma konsentrasi garam menunjukkan pengaruh nyata terhadap aroma sauerkraut $\alpha=0,05$ pada sauerkraut.

4. Mutu sauerkraut terbaik diperoleh pada tingkat konsentrasi garam 2,5\%.

5. Uji kadar vitamin $\mathrm{C}$ dan kadar asam laktat sauerkraut terbaik (konsentrasi garam 2,5\%) sebesar 3,29 mg/100 dan kadar $1,86 \%$.

\section{DAFTAR PUSTAKA}

AOAC. 2006. Official Methods of The Association of Official Analytical Chemistry. AOAC, Int : Washington D. C.

Badan Standardisasi Nasional. 1992. Sauerkraut dalam Kemasan. SNI 012600-1992. Jakarta

Badan Standardisasi Nasional. 1992. Wortel. SNI 01-3163-1992. Jakarta

Badan Standarisasi Nasional. 1998. SNI 013174-1998. Standar Mutu Kubis. Jakarta

Badan Standarisasi Nasional. 2006. SNI 012346-2006. Petunjuk Pengujian Organoleptik dan atau Sensori. Jakarta

Buckle, K.A., Edward, R.A., Fleet, G.H., Wootton. 2007. Ilmu Pangan. Edisi ke4. Terjemahan: Hari Purnomo dan Adiono. UI-Press. Jakarta

Cahyono, B. 2008. Cara Meningkatkan Budidaya Kubis. PT Kanisius.Yogyakarta

Gardjito, M., Handayani., W. Salfarino, R.2015.Penanganan Segar Hortikultura untuk Penyimpanan dan Pemasaran.Fajar Interpratama Mandiri. Jakarta

Hayati, R., Fadhil, R.., Agustina, R. 2017. Analisis Kualitas Sauerkraut (Asinan Jerman) Dari Kol (Brassica oleracea) Selama Fermentasi Dengan Variasi Konsentrasi Garam. Jurnal Rona Teknik Pertanian. Banda Aceh. 
Huzaibah, E., Gobel, M., Asrawaty. 2018. Kualitas Kimia dan Organoleptik Burger Ikan Tuna Yang Disubtitusi Dengan Tepung Buah Mengkudu (Morinda citrifolia). Jurnal Pengolahan Pangan, Vol. 3 (1): 1-8.

Kartika, P.N., Nisa, F.C. 2015. Study Pembuatan Osmodehidrat Buah Nanas (Ananas comosus L. Merr): Kajian Konsentrasi Gula Dalam Larutan Osmosis dan Lama Perendaman. Jurnal Pangan dan Agroindustri. Malang

Kementerian Kesehatan Republik Indonesia. 2018. Data Komposisi Pangan Indonesia.http://www.panganku.org/ id-ID/view. Diakses tanggal 20 September 2018.

Kementerian Pertanian Republik Indonesia. 2017. Statistik Pertanian 2017. Pusat Data dan Sistem Informasi Pertanian. Jakarta.

Khumalawati, I.S, Ulfa, Y. M.2010. Pemanfaatan Limbah Kubis Menjadi Asam Laktat. Jurnal Teknik Kimia. Semarang.

Koswara, S. 2009. Teknologi Pengolahan Sayuran dan Buah-Buahan (Teori dan Praktek). eBookPangan.com. Diakses tanggal 03 September 2018.

Makmun, C. 2007.Wortel Komoditas Ekspor yang Gampang Dibudidayakan.

Hortikultura: 32.

Malasari. 2005. Sifat Fisik dan Organoleptik nugget Ayam dengan Penambahan Wortel (Daucus carota L.) [skripsi]. Fakultas Peternakan. Institut Pertanian Bogor.Bogor.

Muchtadi, T.R,. Sugiyono, Ayustaningwarno, F.2010. Teknologi Proses Pengolahan Pangan. Penerbit Alfabeta. Bandung.

Muchtadi, T.R,. Sugiyono, Ayustaningwarno, F.2013. Ilmu Pengetahuan Bahan Pangan. Penerbit Alfabeta. Bandung. Mulyanto. 2009. Potensi Limbah Pasar Sayur Menjadi Starter Fermentasi.Jurnal
Kesehatan Jurusan Nutisi Dan Makanan Ternak Fakultas Peternakan Universitas Diponegoro. Semarang.

National Nutrient Database for Standard Reference Legacy Release.2018. Basic Report: 11439, Sauerkraut, canned, solids

and

liquids.https://ndb.nal.usda.gov/.Diak ses tanggal 20 September 2018.

Pundir, R.K., Jain, P.2010.Change in Microflora of Sauerkraut During Fermentation and Storage.World Journal of Dairy and Food Sciences 5(2):221-225

Saraswanti Indo Genetech. Diagram Alir Metode Uji Penetapan Kadar Vitamin C Secara HPLC.2017.SIG Laboratory.Bogor.

Saraswanti Indo Genetech. Diagram Alir Pengujian Vitamin Larut Lemak (Vitamin $A, D$ dan E) Secara HPLC.2015.SIG Laboratory.Bogor.

Saraswanti Indo Genetech. Diagram Alur Penetapan Kadae As. Organik Metode HPLC.2017.SIG Laboratory.Bogor.

Setyawan, N dan Widaningrum. 2013. Pengaruh suhu penggorengan vakum dan cara pembumbuan terhadap karakteristik keripik wortel. J. Pascapanen. 10(2): 106-115

Simpson, M.G. 2016. Plant Systematics. Elsevier Academic Press. USA.

Subagjo, A. 2007. Manajemen Pengolahan Roti dan Kue. Graha Ilmu. Yogyakarta

Sunarjono, H.H. 2011. Bertanam 30 Jenis Sayur. Penebar Swadaya. Jakarta.

Susilowati, S., dan Handini. 2016. Uji Kimia, Mikrobiologi dan Organoleptik "Indonesian Sauerkraut" dengan Cabai dan Bawang Putih. Jurnal Universitas Katolik Widya Karya. Malang.

Swain, M.R., Anandharaj, M., Ray, R.C., Rani, R.P.2014. Fermented Fruits and Vegetables of Asia: A Potential Source of Probiotics. Biotechnology Research International. Tamil Nadu. 
Yusmarini., Indrati, R. Utami, T., Marsono, Y.

Kedelai. Jurnal Teknologi Dan 2010. Aktivitas Proteolitik Bakteri Industry Pangan, Vol. 21 (2): 129-134. Asam Laktat dalam Fermentasi Susu 